\title{
A Feasible Study on Cooperative Learning in Large Class College English Teaching
}

\author{
Hua Nan \\ Faculty of Education, Southwest University, Chongqing, China; \\ School of Foreign Languages, Guangxi University of Science and Technology, Liuzhou, China
}

\begin{abstract}
As one of the creative and efficient teaching model, cooperative learning is widely applied to modern English language classroom. However, its feasibility and effectiveness still need further research, especially in large class English teaching for non-English majors. In the paper, two large classes with more than 100 students are involved in this research. In order to make the experiment as practical and persuasive as possible, the author employs some research techniques of questionnaire, data collection and analysis, pre-test and post-test and findings. Eventually it indicates that cooperative learning is effective to a certain degree in large class English teaching and promotes the academic achievement of learners.
\end{abstract}

Index Terms - feasible study, cooperative learning, large class English teaching

\section{INTRODUCTION}

With the great development of higher education in China, the number of college students has gone up at an overwhelming rate in the past fifteen years. This mainly leads to shortage of English teachers and students' number increase. It's impossible for most of colleges and universities in China to organize small classes with the ideal class size of less than 30 students for English language teaching and learning and so large classes with more than 45 students become inevitable. The students have to sit together in a large classroom and quietly listen to the teachers without interaction and communication. Though problems with large-size class appear and teachers and students dislike teaching and learning in a classroom with large size, especially in English language teaching and learning, large classes certainly exist in the present situation and can't be altered in a long period in China. But the only alternative is to improve the approaches in the current classroom context. To improve college English teaching in large classes, teachers have turned to some appropriate teaching approaches, of which the strategy of cooperative learning is quite practical. The paper explores whether or not cooperative learning is feasible or effective in college English classroom with large size in China through questionnaires and findings.

\section{LARge Class CoOPERATIVE LEARNING}

Cooperative learning is defined as group learning activities organized so that learning is dependent on the socially structured exchange of information between learners in groups and in which each learner is held accountable for his or her own learning and is motivated to increase the learning of others. (Yuan Ximing, 2003)As one of the creative and efficient teaching model, cooperative learning not only draws attention to group work or task-based interaction, but also drives learners to participate in a certain learning task actively. Moreover, it is a kind of teaching strategy to develop the students' abilities to learn independently and autonomously in order to meet their need of learning in the form of group work. During the process of cooperative learning, students generally work together in face-to face groups. They spend a large amount of time participating in discussing and assisting one another. So it is called "the most successful teaching reform". Many educators propose some wonderful ideas of cooperative learning in large class.

David Johnson, Roger Johnson, and Holubec (1990) assert that "what we know about effective instruction indicates that cooperative learning should be used when we want students to learn more, like school better, like each other better, like themselves better, and learn more effective social skills."(p.5)

Richard Felder has said, "Cooperative learning is especially important for large classes, where getting students engaged is usually a challenge. The larger the class, the more imperative it is to use cooperative learning." (Guo Xiangju, 2004)

Johnson's research also indicates that getting students to do things in small groups is the only conceivable way for students participating in teaching and learning activities in large classes. In small groups, a teacher can immediately make everyone in a large class participate in learning activities. Shy students are more likely to ask and answer questions in a small group. The same is true of low-skilled students. The benefit of cooperative learning is obvious in language classroom.

Though many experts tell us more about cooperative learning in language teaching, we still need do further research on its feasibility and effectiveness, especially in large class English teaching for Chinese non-English majors. These will be the main concerns of my paper. 


\section{QUESTIONNAIRES AND ANALYSIS}

This study aims at exploring whether or not cooperative learning is feasible or effective in a large class college English teaching. To this point, two large classes with more than 100 students participate in this research. In order to make the experiment as practical and persuasive as possible, the author employs some research techniques of questionnaire, data collection and analysis, pre-test and post-test and findings.

\section{A. Subjects}

The subjects include non-English undergraduates from two different classes in two different departments of Guangxi University of Science and Technology (GXUST). They are all from Grade 2013. Appointed to act as their English teacher, the author has a chance to do research on the two classes. To carry out the experiment, the author regards 78 students from Financial Management Department as the experimental class which is exposed to the cooperative learning approach and 98 students from Computer Engineering Department as the control class which receives conventional competitive and individual learning methods.

\section{B. Data Collection and Analysis}

\section{1) Data Collection of Questionnaire 1}

Two questionnaires are used at the beginning and the end of the experiment respectively. The questions are designed by the author in relevance to cooperative learning and large class teaching references. 176 questionnaires are delivered to the above two classes. At last 170 effective questionnaire ones are received (except six students asking for leave) at the beginning of the experiment.

\section{2) Data Analysis of Questionnaire 1}

Questionnaire 1, including 10 questions is administered for the experimental class as well as the control class. The purpose is to mainly get a thorough understanding of students' learning experience which consists of learners' English language learning environment, learning behavior in English language classroom, and expectation of large class English learning and some main factors that influence students' English language learning before the experiment.

The following investigation problems come from Questionnaire 1 that is filled out by students in both the experimental class and the control class. It provides useful information about students' English language learning before the experiment.

TABLE 1:

STUDENTS' LEARNING ENVIRONMENT IN ENGLISH LANGUAGE CLASSROOM

\begin{tabular}{|c|c|c|c|}
\hline Questions & Items & Number & Percentage \\
\hline \multirow[t]{3}{*}{ The class that you have had } & teachers' professing & 127 & 74.69 \\
\hline & students' cooperative learning & 4 & 2.48 \\
\hline & both of them & 39 & 20.03 \\
\hline \multirow{3}{*}{$\begin{array}{l}\text { You have a chance to answer } \\
\text { questions in class }\end{array}$} & not often & 139 & 81.72 \\
\hline & often & 27 & 15.80 \\
\hline & never & 4 & 2.48 \\
\hline \multirow{3}{*}{$\begin{array}{l}\text { Under which conditions you will } \\
\text { feel the most nervous }\end{array}$} & answering questions in public & 137 & 80.68 \\
\hline & answering questions after discussing & 10 & 5.26 \\
\hline & preparing ahead & 23 & 14.06 \\
\hline \multirow[t]{3}{*}{ The general classroom environment } & anxious & 119 & 70.20 \\
\hline & serious & 42 & 24.78 \\
\hline & relaxed & 9 & 5.02 \\
\hline
\end{tabular}

Table 1 indicates in large class most students are mainly (74.69\%) dominated by the teacher's professing. $81.72 \%$ of students don't often have a chance to answer questions in class, and $80.68 \%$ learners think of answering questions in public as the most nervous situation. The general classroom environment falls into three categories: anxious, serious and relaxed. But $70.20 \%$ of students feel anxious. Therefore even if the teachers talk more about knowledge in classroom environment, the students are not sure whether they learn more or not. What's more, the general classroom environment makes students feel anxious. 
TABLE 2:

STUDENTS' LEARNING BEHAVIOR IN ENGLISH LANGUAGE CLASSROOM

\begin{tabular}{|c|c|c|c|}
\hline Questions & Items & Number & Percentage \\
\hline \multirow{3}{*}{$\begin{array}{l}\text { You often do what in the large } \\
\text { English class }\end{array}$} & listen and answer question actively & 18 & 10.30 \\
\hline & listen and don't answer questions & 120 & 70.60 \\
\hline & feel absent-minded & 32 & 19.10 \\
\hline \multirow{2}{*}{$\begin{array}{l}\text { How you solve some difficulties in } \\
\text { English learning }\end{array}$} & discuss with other classmates & 6 & 3.68 \\
\hline & ask for teachers & 54 & 41.76 \\
\hline $\begin{array}{l}\text { How you do exercises assigned by } \\
\text { teachers }\end{array}$ & don't care & 13 & 7.44 \\
\hline \multirow{3}{*}{$\begin{array}{l}\text { What you do when other students } \\
\text { answer questions }\end{array}$} & listen seriously & 69 & 40.54 \\
\hline & don't listen & 19 & 11.2 \\
\hline & would like to listen but easily absent-minded & 82 & 48.26 \\
\hline
\end{tabular}

From the above table, $70.60 \%$ of the students listen to the teachers but are not willing to participate in answering questions. Moreover $19.10 \%$ of the students even always feel absent-minded during classroom time. Interaction seldom happens between teachers and students. What's more, when they have some difficulties in English language learning, 64.56 of them usually think about questions by themselves. Even when others answer questions, $48.26 \%$ of them could not understand clearly and are absent-minded for not listening. It indicates that English language learning in large class lacks of cooperation in group work.

TABLE 3:

THE MAIN FACTORS THAT INFLUENCE STUDENTS’ ENGLISH LANGUAGE LEARNING

\begin{tabular}{|l|l|l|l|}
\hline Questions & Items & Number & Percentage \\
\hline The main factors that influence your & English level & 26 & 15.25 \\
\cline { 2 - 4 } English language learning & character of being shy & 75 & 44.26 \\
\cline { 2 - 5 } & environment of being nervousness & 69 & 40.49 \\
\hline
\end{tabular}

Table 3 emphasizes although individual English level influences their English language learning, the main two factors that influence students' English language learning include students' character of being shy and environment of being nervousness. Therefore, the ways on how to solve these emotional questions are to make use of cooperative learning in group work in large class.

TABLE 4:

STUDENTS' EXPECTATION OF ENGLISH LANGUAGE LEARNING IN LARGE CLASS

\begin{tabular}{|c|c|c|c|}
\hline Questions & Items & Number & Percentage \\
\hline \multirow{3}{*}{$\begin{array}{l}\text { You expect what classroom model in } \\
\text { the future English language learning }\end{array}$} & teachers' professing & 38 & 22.16 \\
\hline & student-centered activities & 129 & 75.60 \\
\hline & don't care & 7 & 2.24 \\
\hline
\end{tabular}

From table 4, we may see that students hope the classroom model could be changed in the future. The majority $(75.60 \%)$ of them expect more student-centered activities. Cooperative learning is most likely to embody student-centered ideas. In the student-centered activities, students will feel independent and autonomous so that they could stimulate their motivation and interests of English language learning by cooperating in group work in large class.

3) Data Analysis of Questionnaire 2

Questionnaire 2 is administered only for the experimental class. Through the questions, the researcher intend to have a clear picture of students' impressions of the cooperative learning (CL) classroom environment, cooperative learning behavior, cooperative learning emotion and cooperative learning effectiveness in English language classroom. The main purpose is to prove whether or not there are significant changes in the terms of motivation and emotion such as interest and confidence in order and whether cooperative learning is effective or not. 78 questionnaires are delivered to the experiment class. At last 76 effective questionnaire ones are received (except two students asking for leave) at the end of the experiment.

TABLE 1:

STUDENTS’ COOPERATIVE LEARNING ENVIRONMENT IN ENGLISH LANGUAGE CLASSROOM

\begin{tabular}{|c|c|c|c|}
\hline Questions & Items & Number & Percentage \\
\hline \multirow{3}{*}{$\begin{array}{l}\text { The general environment of English } \\
\text { language teaching in large class after } \\
\text { implementing cooperative learning }\end{array}$} & active & 62 & 81.21 \\
\hline & boring & 3 & 4.27 \\
\hline & not obvious & 11 & 14.52 \\
\hline \multirow{3}{*}{$\begin{array}{l}\text { How many chances you make use of } \\
\text { oral English in large class }\end{array}$} & many & 61 & 80.62 \\
\hline & few & 4 & 5.53 \\
\hline & no & 11 & 14.85 \\
\hline
\end{tabular}

English learning environment is necessary for students to learn English well. If there is a better environment students are willing to participate in the activities organized by teachers and don't feel bored. From the above results, under the circumstances of cooperative learning $81.21 \%$ of the students think the general class environment is active and relaxed 
and beneficial for students' English language learning and few students feel bored. Moreover, $80.62 \%$ of them have more chances to speak in English.

TABLE 2:

STUDENTS' LEARNING BEHAVIOR IN ENGLISH LANGUAGE CLASSROOM

\begin{tabular}{|c|c|c|c|}
\hline Questions & Items & Number & Percentage \\
\hline \multirow{3}{*}{$\begin{array}{l}\text { The activity of learning English } \\
\text { compared with before }\end{array}$} & passive & 66 & 86.82 \\
\hline & negative & 6 & 8.18 \\
\hline & not clear & 4 & 5.00 \\
\hline \multirow{2}{*}{$\begin{array}{l}\text { The performance of your answering } \\
\text { question in English language learning }\end{array}$} & Listening and not actively answering & 8 & 10.74 \\
\hline & actively answering more times & 68 & 89.26 \\
\hline \multirow{3}{*}{$\begin{array}{l}\text { The information that other classmates } \\
\text { provide in the course of group work }\end{array}$} & more productive information you don't know & 59 & 77.23 \\
\hline & the same as ones you know & 3 & 4.28 \\
\hline & Some information you know and others you don't know & 14 & 28.49 \\
\hline \multirow{2}{*}{$\begin{array}{l}\text { How you solve some difficulties in the } \\
\text { process of group work }\end{array}$} & group members offer many ways & 68 & 90.13 \\
\hline & $\begin{array}{l}\text { the suggestion that group members offer is not helpful } \\
\text { for you }\end{array}$ & 8 & 9.87 \\
\hline
\end{tabular}

During the process of cooperative learning in classroom, its ideas have an effect on students' behavior. The above table illustrates that $86.82 \%$ of students tend to be more active in English learning when they have a cooperative learning. $89.26 \%$ of them are active participants in classroom and vote in favor of the cooperative learning environment. Moreover it indicates that group work, to a considerable degree, produces an information gap between students, which motivates learning. When talking with each other, they could actively offer productive information, suggestions and error correction. Meanwhile $90.13 \%$ of students feel that they can solve some difficulties in the process of group work and at the same time they improve greatly in their English listening and speaking.

TABLE 3:

STUDENTS' LEARNING EMOTION IN ENGLISH LANGUAGE CLASSROOM

\begin{tabular}{|c|c|c|c|}
\hline Questions & Items & Number & Percentage \\
\hline \multirow{3}{*}{$\begin{array}{l}\text { The sense of anxiety during the } \\
\text { process of communication with other } \\
\text { classmates }\end{array}$} & increasing & 2 & 3.16 \\
\hline & reducing & 61 & 80.36 \\
\hline & not obvious & 13 & 16.58 \\
\hline \multirow{3}{*}{$\begin{array}{l}\text { The interest of learning English } \\
\text { compared with before }\end{array}$} & increasing & 66 & 86.53 \\
\hline & reducing & 3 & 4.13 \\
\hline & not obvious & 7 & 9.34 \\
\hline $\begin{array}{l}\text { The confidence of learning English } \\
\text { compared with before }\end{array}$ & not obvious & 10 & 13.16 \\
\hline
\end{tabular}

Emotion plays an important role in English language learning. If they have no interest or confidence in English language learning, the students aren't willing to speak in English or use English. During cooperative learning experiment the author finds that students believe that cooperative learning helps reduce their anxiety level and motivate their learning interest and increase their confidence. $80.36 \%$ of students' anxiety decreases in an English classroom. Most of them believe their interest and confidence are improved considerably. Thus it greatly proves that cooperative learning is beneficial for students' learning emotion.

TABLE 4:

STUDENTS' COOPERATIVE LEARNING EFFECTIVENESS IN ENGLISH LANGUAGE CLASSROOM

\begin{tabular}{|l|l|l|l|}
\hline Questions & Items & Number & Percentage \\
\hline $\begin{array}{l}\text { How you think of cooperative } \\
\text { learning in large class }\end{array}$ & very effective & 61 & 80.18 \\
\cline { 2 - 4 } & not very effective & 9 & 12.16 \\
\hline
\end{tabular}

Value of cooperative mainly embodies its effectiveness. From questionnaire results it reveals that $80.18 \%$ of the students think of cooperative learning as a suitable and effective teaching method which provides more opportunities for students to practice English and interact with other classmates. Students feel they have progressed especially in speaking and listening with the cooperative approach.

\section{4) Data Analysis of Test Scores}

At the beginning of the first semester the author gives a pre-test for every student in both the experiment class and the control class. The pre-test consists of five parts: listening comprehension, reading comprehension, vocabulary and structure, cloze, and writing. The main purpose of organizing the pre-test is to understand the students' past English learning and find out some factors on how to make more progress in learning English for the classes involved in the experiment. After the first semester is over, a post-test is held by the Foreign Language Department of GXUST. Certainly, all the students are required to take part in the post-test, which aims at measuring whether the students are up to the requirements of band one after English study of one semester and whether the experiment class performs better than the control class by comparing the two tests. 
TABLE 3:

PRE-TEST SCORES

\begin{tabular}{|l|l|l|}
\hline Average Score & Experimental Class & Control Class \\
\hline Total scores & 68.39 & 67.48 \\
\hline Listening/speaking & $10 / 5$ & $10.13 / 5.12$ \\
\hline Reading & 20 & 19.62 \\
\hline V\&S & 10.21 & 10.36 \\
\hline Writing & 9.31 & 9.25 \\
\hline
\end{tabular}

(V\&S=Vocabulary and Structure)

TABLE 4:

POST-TEST SCORES

\begin{tabular}{|l|l|l|}
\hline Average Score & Experimental Class & Control Class \\
\hline Total scores (Average) & 74.69 & 65.23 \\
\hline Listening/speaking & $12.20 / 9$ & $8.54 / 6$ \\
\hline Reading & 26 & 24 \\
\hline V\&S & 13 & 8 \\
\hline Writing & $12 \quad$ (V\&S=Vocabulary and Structure) \\
\hline \multicolumn{1}{|l|}{}
\end{tabular}

From pre-test score, there is almost no difference between the experimental class and control class. However, from post-test score we find that the experimental class performs better than the control class with cooperative learning for one semester. In the above two tables, the total score of the experimental class's final (74.69) is higher than that of control class's (65.23). The listening and speaking ability of the experimental class (12.20/9) is better than control class's (8.54/6) in the test. But although the score of the experimental class's (12) in writing ability is slightly higher than that of control class (11.68), there is no significant difference between the two classes.

Hence, according to the above analysis, cooperative learning is feasible or effective to a certain degree in large class English teaching and promotes the academic achievement of learners.

\section{FINDINGS}

Having carried on the large class English language teaching and learning with the cooperative learning approach for one semester, the author feels different from the small class in English language teaching and learning and experiences many benefits during the process of cooperative learning in college English language teaching and learning as follows:

1) Cooperative learning in large class college English teaching stimulates students' interest in English learning and improves students' language comprehensive abilities.

Piaget, a famous psychologist, has said all intellectual work depends on interest. However, in traditional language classroom teacher often teaches instead of students learning. Teachers usually pours their own designed content into students and don't think about students' interest and what knowledge students need. As time goes on, class becomes more and more boring, and students gradually lose their own interest in language learning. Therefore, English teachers should highlight cooperative relationships in teaching and learning. Teachers should build an active learning environment, inspire students' individual interest in learning and boost communication and interaction between teachers and students or among students in large classes. Group work is usually regarded as basic cooperative learning. Students are reasonably divided into groups according to different levels and each group should be approximately the same. Generally speaking, four or five students in a group are better because too many students in a group easily cause the problems in order and discipline in spite of abundant information. Cooperation in the same group and active competition among groups greatly improves teamwork spirit and the ability to explore problems and motivates interest in learning.

For example, during the process of teaching the article entitled "Environmental Protection Throughout the World" (Unit 2, Book 2, New Horizon College English ), the author uses cooperative learning into teaching as the follows:

dividing groups $\longrightarrow$ interaction between students and computer $\longrightarrow$ task driving $\longrightarrow$ cooperative learning

Firstly, the author divides the students into many groups, and then presents the content of the text in the form of pictures of the polluted Liujiang River with PPT. With the teacher's explanation, the students naturally enter study of the new text. Meanwhile, this kind of presentation also motivates students' interest in learning the text. Then, the teacher asks one question such as "How do we protect the Liujiang River?". To answer this question, students begin to discuss it actively. So the class becomes enlivened. With the help of the group, even some students who are poor in English speaking can speak out some sentences such as "Before Liujiang River is clean. Now it's polluted." Some better students would say more like "Liujiang River is our mother river. She offers us rich water resource. Without her we couldn't live. So we should take effective measures to protect it in order not to be polluted."

2) Cooperative learning in large class college English teaching enlarges the student s' participating number and makes teaching more effective.

Once a teacher has the basic ideas of modern teaching such as student participation, group cooperation, experiencing success and diverse development, students' participation comes first and exists in any form of teaching. Moreover, 
group cooperation changes students from negative accepters into active participants, and encourages all the students to devote themselves to English learning. However, in traditional language teaching, the teacher often asks questions in front of the whole class, and later just arranges one or a few "good students" to answer these questions. This teaching model of "teacher asking - student answering" seems to show that the students have taken part in the course as the active subject, but the fact is that most students just listen without thinking. Most students actually don't participate in the teaching and learning or don't get the benefit from teaching. This results in a breakdown between teaching and learning, which isn't suitable to the principle of students-central.

For instance, here is one paragraph from "Time-Conscious Americans" (Unit 1, Book 2, New horizon College English):

Americans believe no one stands still. If you are not moving ahead, you are falling behind. This attitude results in a nation of people committed to researching, experiencing and exploring. Time is one of the two elements that Americans save carefully, the other being labor.

At the beginning, the author doesn't ask the students to answer questions like these "What is the usage of the word 'result'? What structure is 'the other being labor?"' Instead, the teacher requires the divided groups to discuss these questions together and encourages them to find out more questions. With task driving, the groups begin to discuss questions cooperatively and actively, which naturally makes the course active. As a result, many groups not only could find out the difference between "result in" and "result from," but also they could know the usages of other phrases such as "as a result", "as a result of".

Through cooperative discussion, the students learn to emphasize the meaning of language besides the word itself. Also, different students with different English levels have the chance to take part in the discussion. All the actions is very helpful in finding the key to the questions and the improvement of practical language ability. In the end, the teacher should ask a representative of every group to answer the questions to examine the teaching effect and discover problems that still exist. To sum up, it is necessary to use cooperative learning in college English teaching. It is better to inspire students' interest in English learning, expand student participation, and improve students' cooperative spirit and language communication competence.

3) Cooperative learning in large class college English teaching reaches the aim of changing the teaching model from the traditional teacher-centered model to the student-centered model.

College English Curriculum Requirements (2007) points out the objective of College English will be able to enhance students' ability to study independently and improve their cultural quality so as to meet the needs of China's social development and international exchanges. The reasons for these are as follows. Firstly, the students lack ability to study independently. They depend excessively on teachers instead of learning knowledge and skills voluntarily and get used to relying on teachers' explanations. In addition, traditional thoughts and teaching methods have influenced the teachers. In class, they focus on their own teaching and even take forceful measures to sustain the process of class teaching. Because of this method, students hardly develop abilities of using language and independent study. In recent years, researchers in self-reliant learning all over the world highlight the interaction among students (or groups) and suggest that students be encouraged to learn independently in the form of group work or cooperative study, etc. This means that students should solve the problems by communicating with other group members, negotiating and cooperating with the teacher's help. In this way, students are stimulated to study independently. At the same time, the traditional teaching model of teacher-central has been changed into the new one, in which the teacher acts as a real guide, cooperator and supervisor rather than an authority in students' study.

For example, checking the exercise "Marriage Across the Nations" (Unit 3, Book 2, New Horizon College English), the author invites one of the students to act as a teacher. At first, this student is told to read the sentence of the exercise. "I firmly believe that this agreement will be for our __ benefit." Then he asks other students to fill in the blank, and later he presents the right answer. In this way, the teacher is liberated from teaching activities in the class. Meanwhile, he or she leads the students to try to explore the question and answer it independently. Besides, the students are encouraged to learn actively, and also they can experience the feeling of achievement in the process of learning. On the other hand, they can discover that they should stimulate themselves to improve their own ability of learning independently. With this new method, the traditional teaching model of teacher-central has been changed into the ability of students' self-reliant learning completely.

The effects of cooperative learning are too numerous to be stated one by one. But it's not hard to find implementation of cooperative learning in large English teaching is feasible and effective.

\section{CONCLUSION}

In the new century, there are many requirements for college graduates including at least mastery of a foreign language, competence in IT(Information Technology) and ability of cooperation and creation. Cooperation in large college English classes not only can enable students to develop a sense of cooperation to strengthen their competitiveness in their future work, but also it can help them to develop learning skills. As a new teaching and learning approach, cooperative learning will undoubtedly have a bright prospect in the field of second language teaching, especially in large class college English teaching for non-English majors. 


\section{REFERENCES}

[1] Higher Educational Department of Ministry of National of Education. (2007).College English Curriculum and Instruction Requirement. Beijing: Foreign Language Teaching and Research Press.

[2] Johnson, D. W. \& Johnson, R. T. \& Holubec, E. J. (1990). Circles of Learning: Cooperation in the Classroom. Edina, MN: Interaction Book.

[3] Piaget, J. (1950). The Language and Thought of the Child. New York: Harcourt Brace.

[4] Guo Xiangju. (2004). (4).Cooperative learning in Large Class. CELEA Journal, 4, 120-123.

[5] Wang Yuehui. (2002). A Study of Cooperative Learning in EFL Teaching. M.A. dissertation, Northwestern Polytechnical University.

[6] Yuan Ximing. (2003). The Effectiveness Of Collaborative Learning in EFL Large Class Teaching. M.A. dissertation, Northwestern Polytechnical University.

[7] Zheng Shutang. (2004). New Horizon College English. Beijing: Foreign Language Teaching and Research Press.

Hua Nan was born in Huanggang, Hubei, China in 1973. He received his M.A. degree in education from Guangxi Normal University, Guilin, China in 2005.

$\mathrm{He}$ is currently an associate professor in the School of Foreign Languages, Guangxi University of Science and Technology, Liuzhou, Guangxi, China. His research interests include English Curriculum and Instruction, teacher education and the second language acquisition.

Now he is a doctorate student at Faculty of Education, Southwest University, Chongqing, China. 